\title{
STUDIES ON FIBRINOLYSIN USING A CLINICALLY PRACTICAL METHOD OF QUANTITATIVE DETERMINATION
}

\author{
BY \\ EDWARD ADELSON AND WILLIAM H. ROEDER \\ From the Department of Hematology, Walter Reed Army Institute of Research, Walter Reed Army \\ Medical Center, Washington 12, D.C., U.S.A.
}

(RECEIVED FOR PUBLICATION APRIL 23, 1957)

Methods of quantitative measurement of fibrinolysin are available (Astrup and Alkjaersig, 1952 ; Loomis, George, and Ryder, 1947 ; Shulman and Tagnon, 1950). For the most part, these are fairly complicated techniques suitable for the research laboratory but not for the routine clinical laboratory. The method most generally used in the clinical laboratory is a simple qualitative technique in which the blood clot is incubated overnight at $37^{\circ} \mathrm{C}$. However, this method may give false positive results in patients with fibrinogenopenia as seen, for example, in post-partum cases (Weiner, Reid, and Roby, 1950). Fibrinogenopenia has at times been misdiagnosed as fibrinolysin because of this error. The qualitative fibrinolysin test will also give false negative results when the enzyme is present in excess but is not strong enough to cause complete lysis of the clot. In these cases, Macfarlane (1937) has recommended using dilute plasma to bring out the fibrinolytic activity. While this method is an improvement over the blood-clot incubation technique, it may still give false positive and false negative results. Furthermore, it gives only a qualitative measure of the defect. Bidwell (1953) and Bidwell and Macfarlane (1951) have attempted to convert Macfarlane's qualitative technique to a quantitative one, and the method now presented is essentially a modification of this method. The quantitative method to be described is useful for any clinical laboratory that is able to do fibrinogen determinations. It has been applied to the routine investigation of coagulation problems, and in addition has been used to study the characteristics of the fibrinolysin in the plasma of a patient with carcinoma of the prostate.

\section{Methods}

Defibrinogenation of Plasma.-This was carried out in one of two ways: (1) The plasma was heated for three minutes at $56^{\circ} \mathrm{C}$. and was centrifuged for을 five minutes at 1,000 r.p.m. Then the supernatant defibrinogenated plasma was separated. (2) Onec hundred units of thrombin were added to each millilitre of plasma to be defibrinogenated. The clot which formed was squeezed out with a glass rod $₹$ and removed, leaving behind the defibrinogenated $\vec{\varphi}$ material.

Activation of Pro-fibrinolysin.-Two methods were used. The chloroform technique (Tagnon, 1942) foro activation of pro-fibrinolysin consisted of adding $0.1 \mathrm{ml}$. of chloroform plus $0.04 \mathrm{ml}$. of $0.5 \mathrm{M} \mathrm{CaCl}_{2} \bar{O}$ to each millilitre of plasma. The mixture was incu- $ֶ$ bated at $37^{\circ} \mathrm{C}$. for 30 minutes, then centrifuged. $\stackrel{\odot}{\circ}$ The chloroform layer was removed. The residual serum was kept uncovered overnight in the refriger-응 ator, and was ready for use the next morning. The varidase method (Loomis, 1955) consisted of adding $0.1 \mathrm{ml}$. of varidase $(10,000$ units of streptokinase and 2,500 units of streptodornase) to each millilitre of plasma. The mixture was incubated for one hour at $37^{\circ} \mathrm{C}$.

Purification of Commercial Fibrinogen.-Bovine fibrinogen (Armour) and Cohn's fraction I (obtained from the American Red Cross) prepared from human plasma were used as the starting material. The puri-음 fication was carried out by Laki's technique (1951).

Fibrin Determination.-Fibrin levels were measured‥ by tyrosine determination using Folin-CiocalteuN (1927) phenol reagent as described by Quick (1951). One millilitre of plasma was diluted to $25 \mathrm{ml}$. with 0 saline or distilled water plus 100 units of thrombin. N The resultant clot was incubated at $37^{\circ} \mathrm{C}$. for various $\sigma$ periods of time as noted below. In the routine fibrin determination, the clot was removed from the $25-\mathrm{ml}$. mixture by winding around a glass stirring rod. This method was not adequate for fibrinolysin studies, + since the clots, especially after long incubation, were $\underline{T}$ extremely fragile. Consequently, fibrin was separated by filtration through a glass wool filter. The glass $\bigcirc$ wool-clot mixture was squeezed out and washed $\overrightarrow{\mathbb{D}}$ repeatedly with $0.9 \%$ saline, and the fibrin content $\sigma$ measured by the routine colorimetric technique of tyrosine determination. 
Source of Plasma with Excess Fibrinolysin.Throughout the work reported in this paper, the actively fibrinolytic plasma was obtained from a 70-year-old man who had carcinoma of the prostate. This patient was first seen because of a bleeding tendency manifested by recurrent spontaneous purpura, finally culminating in a cerebral haemorrhage. He had a bleeding time of 23 minutes (Duke), a clotting time of 8 minutes (Lee, White), a prothrombin content of $60 \%$, and a platelet count (Brecher) of 142,500 per c.mm. A routine fibrinolysin test consisting of 24-hour incubation of whole blood was weakly positive, since the incubated whole blood clot showed only slight breakdown. However, quantitative studies revealed a definite fibrinolytic activity. This patient would probably fit into the group of cases called "fibrinolytic purpura" (Stefanini, 1952).

Procedure. - The technique recommended for measurement of fibrinolysin in clinical laboratories is as follows:

1. Heat fresh normal plasma and test plasma to $56^{\circ} \mathrm{C}$. for three minutes. Cool. Centrifuge. Save supernatants (defibrinogenated plasma).

2. Add $1 \mathrm{ml}$. of normal plasma to each of four tubes labelled $A, B, C$, and $D$.

3. To tubes $A$ and $B$ add $1 \mathrm{ml}$. of defibrinogenated normal plasma. To tubes $C$ and $D$ add $1 \mathrm{ml}$. of defibrinogenated test plasma.

4. Bring total volume in each tube to $24 \mathrm{ml}$. with saline. Place all four tubes in incubator at $37^{\circ} \mathrm{C}$.

5. Add $1 \mathrm{ml}$. of thrombin (100 units per $\mathrm{ml}$.) to each tube.

6. After 15 minutes' incubation, take tubes $A$ and $C$ from water bath. Filter through glass wool. Wash glass wool-clot mixture repeatedly with distilled water. Squeeze out excess moisture.

7. Do tyrosine determinations on both clots.

8. After 24 hours of incubation, carry out steps 6 and 7 on tubes $B$ and $D$.

9. Final results are expressed in terms of percentage loss of fibrin.

\section{Results}

Experiment 1.-In this experiment, 20 tubes were each filled with $24 \mathrm{ml}$. of saline. The tubes were divided into two sets of 10 each. To each of the 10 tubes in set $1,1 \mathrm{ml}$. of normal plasma was added. One millilitre of fibrinolytic plasma was added to each of the 10 tubes in set 2 . All 20 tubes were placed in an incubator at $37^{\circ} \mathrm{C}$. and thrombin was added. At intervals as noted in Fig. 1, two tubes - one from each set-were withdrawn from the incubator and fibrin levels were determined.

The fibrin levels, when plotted against time, gave an S-shaped curve both in the normal subject and in the patient with active fibrinolysin. Often fibrinolytic activity is also fibrinogenolytic.

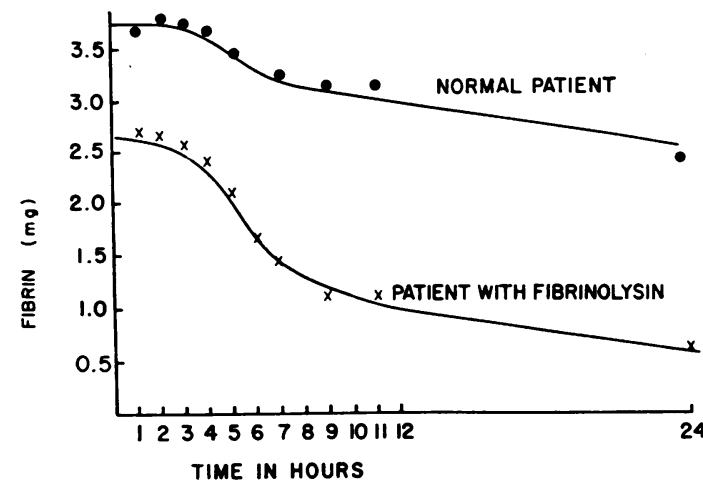

FIG. 1.-Fibrin levels obtained using $1 \mathrm{ml}$. of test plasma as source of both fibrinogen and fibrinolysin. Amount of fibrin is plotted against time of incubation of clot.

In the case of the patient under discussion, however, the fibrinolysin was sufficiently mild so that his plasma fibrinogen level was only slightly lower than the normal. If his starting fibrinogen level (at time 0) were lower, this comparison between normal and patient could not be carried out as readily (Table I).

TABLE I

EFFECT ON FIBRIN DETERMINATION OF VARYING AMOUNT OF SUBSTRATE

\begin{tabular}{|c|c|c|c|c|c|}
\hline $\begin{array}{l}\text { Tube } \\
\text { No. }\end{array}$ & $\begin{array}{c}\text { Defibrino- } \\
\text { genated } \\
\text { Normal } \\
\text { Plasma } \\
\text { (ml.) }\end{array}$ & $\begin{array}{c}\text { Defibrino- } \\
\text { genated } \\
\text { Patient } \\
\text { Plasma } \\
\text { (ml.) }\end{array}$ & $\begin{array}{l}\text { Normal } \\
\text { Plasma } \\
\text { (ml.) }\end{array}$ & $\begin{array}{l}\text { Totai } \\
\text { Fibrin } \\
\text { Content } \\
\text { Stat. } \\
\text { (mg.) }\end{array}$ & $\begin{array}{l}\text { Total } \\
\text { Fibrin } \\
\text { Content } \\
\text { after } \\
24 \mathrm{hr} \text {. } \\
\text { (mg.) }\end{array}$ \\
\hline $\begin{array}{r}1 \\
2 \\
3 \\
4 \\
5 \\
6 \\
7 \\
8 \\
9 \\
10 \\
11 \\
12 \\
13 \\
14 \\
15\end{array}$ & $\begin{array}{l}0 \\
1 \\
0 \\
0 \\
1 \\
0 \\
0 \\
1 \\
0 \\
0 \\
1 \\
0 \\
0 \\
1 \\
0\end{array}$ & $\begin{array}{l}0 \\
0 \\
1 \\
0 \\
0 \\
1 \\
0 \\
0 \\
1 \\
0 \\
0 \\
1 \\
0 \\
0 \\
1\end{array}$ & $\begin{array}{l}2.5 \\
2.5 \\
2.5 \\
1.0 \\
1.0 \\
1.0 \\
0.5 \\
0.5 \\
0.5 \\
0.25 \\
0.25 \\
0.25 \\
0 \cdot 1 \\
0.1 \\
0.1\end{array}$ & $\begin{array}{l}8.90 \\
8.60 \\
8.82 \\
3.62 \\
3.70 \\
3.64 \\
1.74 \\
1 \cdot 82 \\
1.59 \\
0.84 \\
0.90 \\
0.86 \\
0 \cdot 20 \\
0 \cdot 16 \\
0.27\end{array}$ & $\begin{array}{l}6 \cdot 40 \\
5 \cdot 54 \\
4 \cdot 00 \\
3 \cdot 00 \\
2 \cdot 65 \\
1 \cdot 89 \\
1 \cdot 29 \\
1 \cdot 20 \\
0 \cdot 46 \\
0 \cdot 60 \\
0 \\
0 \\
0 \\
0 \\
0\end{array}$ \\
\hline
\end{tabular}

Experiment 2. -The results in experiment 1 are dependent on two variables, fibrinogen and fibrinolytic enzyme. In order to control the former, the source of fibrinogen was changed from the test plasma to a normal "substrate." The substrate, in this case, was $1 \mathrm{ml}$. of normal plasma. The experiment was now set up with $1 \mathrm{ml}$. of substrate plus $1 \mathrm{ml}$. of defibrinogenated test material. In this experiment, the defibrinogenation was carried out by heat at $56^{\circ} \mathrm{C}$. for three minutes. The results with various test materials are shown in Fig. 2, in which a time 


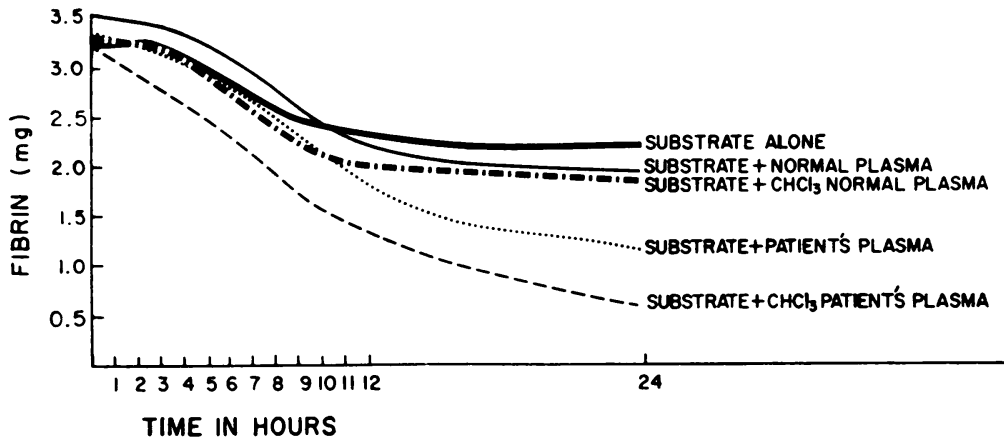

FIG. 2.-Fibrin levels obtained using $1 \mathrm{ml}$. of normal plasma as substrate and $1 \mathrm{ml}$. of defibrinogenated test material as source of fibrinolysin. Amount of fibrin is plotted against time of incubation of clot.

curve was obtained. In Fig. 3 a similar series of samples is demonstrated, but this time only two tubes were set up with each; one was tested after 15 minutes incubation to give the starting fibrin levels, the other after 24 hours.

TABLE II

EFFECT ON FIBRIN DETERMINATION OF VARYING THE AMOUNT OF DEFIBRINOGENATED NORMAL PLASMA

\begin{tabular}{c|c|c|c|c}
$\begin{array}{c}\text { Tube } \\
\text { No. }\end{array}$ & $\begin{array}{c}\text { Defibrinogenated } \\
\text { Normal Plasma } \\
\text { (ml.) }\end{array}$ & $\begin{array}{c}\text { Normal } \\
\text { Plasma } \\
(\mathrm{ml} .)\end{array}$ & $\begin{array}{c}\text { Fibrin } \\
\text { Stat. } \\
(\mathrm{mg} .)\end{array}$ & $\begin{array}{c}\text { Fibrin at } \\
24 \mathrm{hr} . \\
(\mathrm{mg} .)\end{array}$ \\
\hline 1 & 5.0 & 1 & 3.58 & 0 \\
2 & 2.5 & 1 & 3.64 & 0 \\
3 & 1.0 & 1 & 3.70 & $2 \cdot 70$ \\
4 & 0.5 & 1 & 3.62 & $2 \cdot 89$ \\
5 & 0.25 & 1 & 3.70 & 2.99 \\
6 & 0.15 & 1 & 3.62 & 3.10 \\
7 & 0.0 & 1 & 3.66 & 3.18 \\
\hline
\end{tabular}
amount. fibrinogen prepared by Laki $\mathrm{s}$ technique instead of normal plasma was used as substrate. The results obtained a re shown in Table IV. A similar result was obtained using purified human fibrinogen (also prepared by Laki's technique).

In Table $\mathrm{V}$ are presented the results of the proposed m e th od of determining fibrinolytic activity applied to the plasma of 23 normal subjects. The drop in fibrin content during 24 hours' incubation ranged from 3 to $40 \%$ of the original

\section{Discussion}

In experiment 1 an example is presented of fibrinolytic activity in the plasma of a normal $\vec{\theta}$ subject as compared with the activity in the plasma of a patient with carcinoma of the prostate. The result for the normal subject was similar to that obtained in the 23 normal controls similarly tested (Fig. 1 and Table V). Using a qualitative method. Truelove (1953) was also able to demonstrate fibrinolysin in most normal plasmas on 24-hour incubation. Thus, the mere demonstration of fibrinolysis is without pathological significance. The degree of lysis is the important factor. In Fig. 1 it is shown that the

Experiment 3.-In this experiment the effect of varying the amount of substrate was tested. When the substrate fibrinogen level was low enough even a normal amount of fibrinolysin sufficed to produce complete lysis in 24 hours (Table I).

Experiment 4.-In this experiment the effect of varying the amount of test material was determined (Tables II and III). In Table II it is seen that when the amount of test material was large enough even normal concentrations of fibrinolysin produced complete lysis.

Experiment - 5. - In this experiment purified bovine

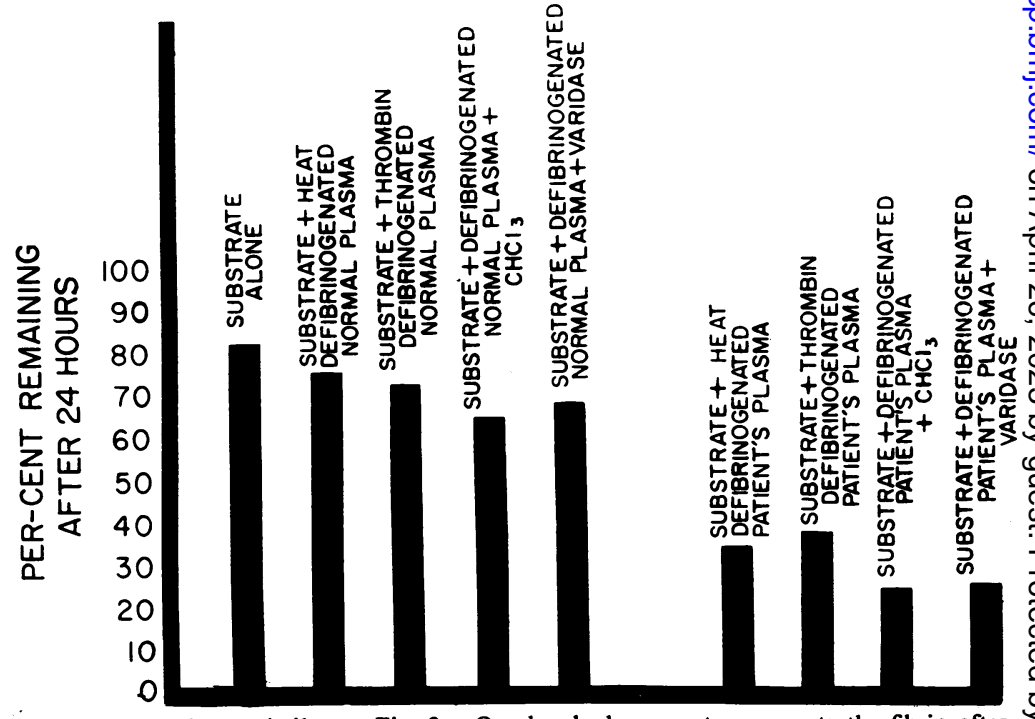

FIG. 3.-Experiment similar to Fig. 2. One hundred per cent, represents the fibrin after 15 minutes' incubation. 
TABLE III

EFFECT ON FIBRIN DETERMINATION OF VARYING THE AMOUNT OF DEFIBRINOGENATED TEST PLASMA

\begin{tabular}{c|c|c|c|c}
$\begin{array}{c}\text { Tube } \\
\text { No. }\end{array}$ & $\begin{array}{c}\text { Defibrinogenated } \\
\text { Patient's Plasma } \\
\text { (ml.) }\end{array}$ & $\begin{array}{c}\text { Normal } \\
\text { Plasma } \\
\text { (ml.) }\end{array}$ & $\begin{array}{c}\text { Fibrin } \\
\text { Stat. } \\
\text { (mg.) }\end{array}$ & $\begin{array}{c}\text { Fibrin } \\
\text { at 24 hr. } \\
\text { (mg.) }\end{array}$ \\
\hline 1 & 5.0 & 1 & 3.95 & 0.0 \\
2 & 2.5 & 1 & 3.72 & 0.0 \\
3 & 1.0 & 1 & 3.63 & 1.17 \\
4 & 0.5 & 1 & 3.84 & 1.28 \\
5 & 0.25 & 1 & 3.72 & 2.00 \\
6 & 0.15 & 1 & 3.63 & 2.15 \\
7 & 0.0 & 1 & 3.60 & 2.40 \\
\hline
\end{tabular}

TABLE IV

USE OF PURIFIED BOVINE FIBRINOGEN AS SUBSTRATE $(1 \mathrm{ml} .=4.00 \mathrm{mg}$.

\begin{tabular}{|c|c|c|c|c|c|}
\hline $\begin{array}{l}\text { Tube } \\
\text { No. }\end{array}$ & $\begin{array}{c}\text { Fibrinogen } \\
\text { Solution } \\
\text { (ml.) }\end{array}$ & $\begin{array}{c}\text { Test Material } \\
\text { (ml.) }\end{array}$ & $\begin{array}{l}\text { Fibrin } \\
\text { Stat. } \\
\text { (mg.) }\end{array}$ & $\begin{array}{c}\text { Fibrin } \\
\text { at } \\
24 \mathrm{hr} . \\
\text { (mg.) }\end{array}$ & Drop \\
\hline $\begin{array}{l}1 \\
2\end{array}$ & 1 & $\frac{0}{1 \text { ml. normal plasma (heat }}$ & $\begin{array}{l}4.06 \\
3.94\end{array}$ & $\begin{array}{l}3 \cdot 50 \\
2 \cdot 99\end{array}$ & $\begin{array}{l}14 \\
24\end{array}$ \\
\hline 3 & 1 & $1 \mathrm{ml}$. normal plasma plus & 427 & $3 \cdot 11$ & 27 \\
\hline 4 & 1 & $\begin{array}{l}1 \mathrm{ml} \text {. patient's plasma (heat } \\
\text { defibrinogenated) }\end{array}$ & $4 \cdot 35$ & $2 \cdot 14$ & 51 \\
\hline 5 & 1 & $\begin{array}{l}1 \text { ml. patient's plasma plus } \\
\text { varidase }\end{array}$ & 3.94 & 1.08 & 73 \\
\hline
\end{tabular}

TABLE V

FIBRINOLYSIS IN PLASMAS FROM 23 NORMAL SUBJECTS

\begin{tabular}{c|c|c|c}
\hline \multicolumn{2}{c|}{ Fibrin Content (mg.) } & \multicolumn{2}{c}{ Decrease of Fibrin } \\
\cline { 1 - 2 } $\begin{array}{c}\text { After 15 Minutes } \\
\text { Incubation }\end{array}$ & $\begin{array}{c}\text { After 24 Hours' } \\
\text { Incubation }\end{array}$ & (mg.) & $(\%)$ \\
\hline 330 & 240 & 90 & 27 \\
474 & 410 & 64 & $13 \cdot 5$ \\
363 & 345 & 18 & 5 \\
439 & 263 & 176 & 40 \\
456 & 386 & 70 & 15 \\
304 & 292 & 12 & 4 \\
350 & 215 & 135 & 39 \\
304 & 252 & 52 & 17 \\
304 & 292 & 12 & 4 \\
370 & 270 & 150 & 27 \\
316 & 287 & 29 & 9 \\
370 & 265 & 105 & 28 \\
310 & 263 & 47 & 15 \\
486 & 410 & 76 & 15 \\
310 & 298 & 12 & 4 \\
304 & 269 & 35 & 12 \\
287 & 281 & 6 & 3 \\
349 & 269 & 80 & 23 \\
252 & 240 & 12 & 5 \\
316 & 287 & 29 & 9 \\
269 & 246 & 23 & $7 \cdot 5$ \\
304 & 295 & 29 & $9 \cdot 5$ \\
333 & 292 & 41 & 12 \\
\hline
\end{tabular}

fibrin content of the clot of the normal patient fell from 380 to $270 \mathrm{mg}$. per $100 \mathrm{ml}$, a loss of $30 \%$, while in the patient with fibrinolysin the loss was from 270 to $60 \mathrm{mg}$., a drop of $80 \%$. Fig. 1 also shows that the curve of loss of fibrin takes a sigmoid form. The first two to three hours of incubation provided very little breakdown of clot. Jacobsson (1955) found a similar lag period which he called the "time lag" of fibrinolysis.
The comparison between normal and abnormal fibrinolytic activity becomes even more important, and perhaps more difficult to assess, when the original concentration of plasma fibrinogen is low. This is a frequent occurrence in patients with abnormal fibrinolytic activity, in diseases of the liver where fibrinogen production may be impaired, and in fibrinolytic states where there may be an associated fibrinogenolysis. Tables I, II, and III clearly show that variations' in the relative proportions of substrate (fibrinogen) and enzyme (fibrinolysis) are important. Table I shows the effect of decreasing the amount of substrate. When fibrinogen levels are sufficiently low, as in tube 11 , even normal fibrinolysin produces complete lysis of clots. This clearly illustrates the danger of mistaking fibrinogenopenia for fibrinolytic activity. Furthermore, when the amount of normal fibrinolysis is increased (as in tubes 1 and 2, Table II), complete lysis of the clot occurs. This suggests that the difference between the fibrinolysin of a normal patient and of the patient with fibrinolytic purpura is a quantitative and not a qualitative one.

To obviate the variability of results because of differences in the relative proportions of substrate and enzyme we recommend that the concentration of the substrate be controlled by removing the native fibrinogen from the test plasma and from a control plasma. A definite amount of normal plasma is then added to each to provide fibrin as the substrate. This not only controls the amount of substrate but also establishes the same preincubation level for both, thus permitting a more valid comparison of the fibrinolytic activity in the two.

The use of normal plasma as substrate is not ideal. Normal plasma, in addition to fibrinogen, supplies many other ingredients among which are pro-fibrinolysin and anti-fibrinolysin. An attempt was made to use bovine fibrinogen purified by the Laki method. The results, shown in Table IV, are similar to those obtained when the substrate was normal plasma (Table II). The $14 \%$ breakdown of the fibrinogen solution alone (Table IV) shows that it was not possible to obtain fibrinogen that was free of fibrinolysin. The techniques which separate fibrinogen from other plasma proteins do not rid fibrinogen of fibrinolysin. For this reason, there seems to be no advantage in using the so-called purified fibrinogen as substrate. Human fibrinogen presented a similar problem. It was not possible to show any species specificity of the fibrinolysin. 
The method recommended for clinical use differs from that of Bidwell and Macfarlane (1951) in two important points: (1) These workers did not defibrinogenate their test plasma and substitute normal plasma as substrate, and (2) they removed the clot after 24 hours' incubation by means of a glass rod. This latter method has been found to be extremely difficult to use, especially in cases with mild fibrinolysis. Consequently, filtration through glass wool is recommended.

It should be stressed that the plasma used in step 1 should not be kept at room temperature or at $37^{\circ} \mathrm{C}$. for too long a period of time before testing, since fibrinolysin is somewhat labile (Jacobsson, 1955; Truelove, 1953) and will decrease in activity on prolonged standing.

A possible criticism of this method may be raised on the grounds that heat defibrinogenation may destroy some of the fibrinolysin. However, Fig. 3 shows that there is no significant difference when defibrinogenation is carried out by heat or by thrombin. Furthermore, the fact that the addition of thrombin does not cause a greater amount of fibrinolysin activity rules out the possibility that the commercial thrombin used could supply significant amounts of fibrinolysin.
Summary

1. A method of quantitative determination of plasma fibrinolytic activity is presented for routine use in the clinical laboratory. This method depends on normal plasma as substrate and defibrinogenated plasma as test material.

2. When substrate fibrinogen is low enough. normal fibrinolysin will cause complete clot lysis.

3 . When the proportion of normal fibrinolysin to substrate is increased, complete lysis of clot will occur.

4. Methods for preparing "pure" fibrinogen do not remove the fibrinolysin, so there is no advantage in using "purified" materials in the test.

\section{REFERENCES}

Astrup, T., and Alkjaersig, N. (1952). Arch. Biochem. Biophys., 3799 Bidwell, E. (1953). Biochem. J., 55, 497.

- and Macfarlane, R. G. (1951). Ibid., 49, xlii.

Folin, O., and Ciocalteu, V. (1927). J. biol. Chem., 73, 627

Jacobsson, K. (1955). Scand. J. clin. Lab. Invest., 7, Suppl. 14. pp. $1-54$.

Laki. K. (1951). Arch. Biochem. Biophys., 32, 317.

Loomis, E. C. (1955). In The Coagulation of Blood, Methods of Stud p. 163, edited by L. M. Tocantins, Grune and Stratton, New York. p.

Macfarlane, C., and Ryder, A. (1947).

Quick, A. J. (1951). The Physiology and Pathology of Hemostasis Lea and Febiger, Philadelphia.

Shulman, N. R., and Tagnon, H. J. (1950). J. biol. Chem., 186, 69

Stefanini, M. (1952). Blood, 7, 1044.

Tagnon, H. J. (1942). J. Lab. clin. Med., 27, 1119.

Truelove, S. C. (1953). Clin. Sci.,12, 75.

Weiner, A. E., Reid, W. B., and Roby, C. C. (1950). Amer, J. Obstet. Gynec., 60, 379 